\title{
Sustainable Streetscape Design Guideline based on Universal Design Principles
}

\author{
Bangun IR Harsritanto ${ }^{* 1}$ \\ ${ }^{1}$ Departement of Architecture, Engineering Faculty, Universitas Diponegoro, Semarang, Indonesia
}

\begin{abstract}
People access the streets to fulfill their daily demands regardless of their gender, age, and abilities. The streetscape is an urban public space which built to facilitate the basic needs of people as social beings. Universal design accommodates the wide range of human diversity in physical appearance, perception, cognitive abilities, body sizes, and shapes. By designing for this diversity, the streetscapes are becoming more user friendly, functional and sustainable. The purpose of this study is to suggest streetscape design guideline based on universal design principles for giving proper directions of sustainable streets development. Literatures study and cases study were used as research methods. The findings indicated that the new guideline based on universal design can be suggested to streetscapes design directions on many countries.
\end{abstract}

\section{Introduction}

Streets roled an important part of open public space and become most influenced symbols of the public area. Streets have functional, social, and leisure needs of people have been associated with economic growth, people physical health, and community senses. Scholars suggest idea of the street as social space instead of only a channel for the movement [1]. People access the street, regardless their sexes, age and abilities for many reasons. The streetscape is an urban fabric that built to facilitate people's basic need as social being. Since people use most of their time on the streets, the role of proper designed streets is important in urban development.

Universal design builds facility designs which provide the full range of potential users, including people with disabilities, various mobility, and other special needs. Universal design suggested integration in streetscape design from origin to destination for the widest possible range of prospect users. Universal design regarded all possible obstacles that may exist in buildings, sidewalks, paths, roads, transportation terminals, and vehicles. The universal design principles may bring the streetscapes become more functional, user friendly, and sustainable.

The studies of universal design application can be done in two ways, the first is done by existing product appraisal and the second by adding more parameters to be next appraisal items. This study referred to the second type of universal design study which added more parameters to be next appraisal items [2].

*Corresponding author: bangunirh@arsitektur.undip.ac.id 
The purpose of this study is to suggest streetscape design guideline based on universal design principles for giving proper directions of sustainable streets development.

\section{Methods}

Literatures study and cases study were used as research methods. This study carries several literatures of streetscapes design guidelines which already referenced by many cities (Barton, Islington, Landcome, Torbay, Scottsdale, Abu Dhabi, Guide dog, etc.), literature of universal design based studies that adopted in many built environment facilities (Center of Universal design, Shehu, Null, Kadir, Goldsmith, et al), and some of related papers to build the evaluation sheet. Furthermore, the constructed evaluation sheet will be assessed to urban design aspect at case studies in Indonesia.

\section{Analysis}

Descriptive analyses were conducted for all study variables. Comparative study holds a simple research by comparing at least two literatures to bring a result. This study uses multi disciplinary in a new guideline.

\section{Discussion and Results}

\subsection{Universal Design}

Universal design is a design philosophy which removed distinctions among various abilities by adhering to four major principles. The principles identified by Ron Mace [3] as follows:

1. Accessible

2. Safety

3. Supportive

4. adaptable

The center for universal design at North Carolina expanded the four principles list into seven principles of universal design. Furthermore. The latest detailed seven principles of universal design become one of the grand theories in this study. They described as:

1. Equitable Use

2. Flexibility in Use

3. Size and Space for Approach and Use

4. Simple and Intuitive Use

5. Low Physical Effort

6. Perceptible Information

7. Tolerance for Error

\subsection{Urban Streetscape}

Urban streetscape is a natural and built fabric of street. Urban Streetscape designs affects the quality and visual effect of the street. It includes street surfaces, buildings, building fixtures and the fittings which facilitate their function to landscape schemes. Urban streetscape created a good environment for people to gather or travel. Social and economic interactions are communal goals of a good street design [4] which also sustainable design. The streets have There are five principal functions of the streets [5], such as : access, movement, place, drainage, utilities, parking; and lighting. 
This study summarized the 7 existing street guidelines, they are :

1. Inclusive design: street for life

2. Islington street book

3. Inclusive streets: design principles for blind and partially sighted people

4. Abu dhabi urban street design manual

5. Landcome street design manual

6. Scottsdale city specialized street design guidelines

7. Torbay specialized street guideline

There were fundamental issues of this new guideline study (see table 1), such as :

1. the previous studies were aimed for tourism facilities $[7,11,12]$ that brought artificial disneyfication of street. This disneyfication of tourism may limits the urban society's natural expression [6].

2. the previous studies were aimed to localize $[9,10]$ that unsustainable for street fabric from and to the site.

3. the previous guidelines were not apply universal design $[4,8]$, so that people with disabilities will be treated as a different kind of person. The facilities were designed specifically only for them mentioned on the literature [13]. The designer should learn about the various needs of people and reduce dependency to other people helps [14].

Table 1. Street guidelines comparisons

\begin{tabular}{|c|c|c|c|c|}
\hline Literature & Purpose & Result & Cons & Pros \\
\hline $\begin{array}{l}\text { Inclusive } \\
\text { Urban } \\
\text { Design [6] }\end{array}$ & $\begin{array}{l}\text { Creating environments that } \\
\text { maximize people's quality } \\
\text { of life-based on dementia } \\
\text { people preference research }\end{array}$ & $\begin{array}{l}\text { Dementia } \\
\text { and } \\
\text { elderly } \\
\text { friendly } \\
\text { street }\end{array}$ & $\begin{array}{l}\text { Concern on } \\
\text { dementia- } \\
\text { elderly }\end{array}$ & $\begin{array}{l}\text { Dementia and } \\
\text { elderly } \\
\text { friendly, } \\
\text { strong } \\
\text { memory/histo } \\
\text { ry aspect }\end{array}$ \\
\hline $\begin{array}{l}\text { Islington } \\
\text { Streetbook } \\
\text { A borough- } \\
\text { wide } \\
\text { streetscape } \\
\text { manual [7] }\end{array}$ & $\begin{array}{l}\text { Built an attractive, safe and } \\
\text { accessible streetscape by } \\
\text { setting guidelines and } \\
\text { specifications }\end{array}$ & $\begin{array}{l}\text { Tourism } \\
\text { streetbook }\end{array}$ & $\begin{array}{l}\text { Concern on } \\
\text { local } \\
\text { tourism }\end{array}$ & $\begin{array}{l}\text { Promote } \\
\text { tourism, } \\
\text { minimal } \\
\text { material use }\end{array}$ \\
\hline $\begin{array}{l}\text { Design } \\
\text { principles } \\
\text { for blind } \\
\text { and } \\
\text { partially } \\
\text { sighted } \\
\text { people [8] }\end{array}$ & $\begin{array}{l}\text { Accommodate the differing } \\
\text { needs and expectations of } \\
\text { all those who use the street } \\
\text { space especially for blind } \\
\text { and partially sight people }\end{array}$ & $\begin{array}{l}\text { Blind and } \\
\text { partially } \\
\text { blind } \\
\text { sighted } \\
\text { street }\end{array}$ & $\begin{array}{l}\text { Concern on } \\
\text { blind-dog } \\
\text { walker }\end{array}$ & $\begin{array}{lr}\text { Blind people } \\
\text { dan dog } \\
\text { walker } \\
\text { friendly }\end{array}$ \\
\hline $\begin{array}{l}\text { Abu Dhabi } \\
\text { Urban } \\
\text { Street } \\
\text { Design } \\
\text { Manual [9] }\end{array}$ & $\begin{array}{l}\text { To design streets that create } \\
\text { a safe environment for all } \\
\text { users, recognizing varying } \\
\text { levels of driver education } \\
\text { and cultural differences }\end{array}$ & $\begin{array}{l}\text { estidama's } \\
\text { principle } \\
\text { on } \\
\text { Abudhabi }\end{array}$ & $\begin{array}{l}\text { Desert } \\
\text { climate } \\
\text { response }\end{array}$ & $\begin{array}{l}\text { Concern on } \\
\text { residential } \\
\text { area }\end{array}$ \\
\hline
\end{tabular}




\begin{tabular}{|c|c|c|c|c|}
\hline Literature & Purpose & Result & Cons & Pros \\
\hline $\begin{array}{l}\text { Street } \\
\text { Design } \\
\text { Guideline } \\
\text { for } \\
\text { Landcome } \\
{[10]}\end{array}$ & $\begin{array}{l}\text { Built environment } \\
\text { providing routes for } \\
\text { vehicles and public } \\
\text { transport and accommodate } \\
\text { utility services and drainage } \\
\text { system }\end{array}$ & $\begin{array}{l}\text { Australia } \\
\text { streetbook } \\
\text { guideline }\end{array}$ & $\begin{array}{l}\text { Concern on } \\
\text { residential } \\
\text { area }\end{array}$ & $\begin{array}{l}\text { Legibility } \\
\text { force, design } \\
\text { community- } \\
\text { based }\end{array}$ \\
\hline $\begin{array}{l}\text { City of } \\
\text { Scottsdale } \\
\text { Streetdesign } \\
\text { guidelines } \\
\text { [11] }\end{array}$ & $\begin{array}{l}\text { Establishing a strong } \\
\text { identity and distinctive } \\
\text { visual character } \\
\text { scottsdale road as } \\
\text { "signature" corridor }\end{array}$ & $\begin{array}{l}\text { Tourism } \\
\text { streetbook }\end{array}$ & $\begin{array}{l}\text { Concern on } \\
\text { local } \\
\text { tourism }\end{array}$ & $\begin{array}{l}\text { Signage } \\
\text { concern, } \\
\text { transit } \\
\text { oriented }\end{array}$ \\
\hline $\begin{array}{l}\text { Torbay } \\
\text { Streetdesign } \\
\text { guidelines } \\
{[12]}\end{array}$ & $\begin{array}{l}\text { Create attractive,pedestrian } \\
\text { environment, pleasant } \\
\text { spaces that encourage } \\
\text { greater pedestrian activity - } \\
\text { with improved safety and } \\
\text { health benefits to the } \\
\text { community, } \\
\text { environmental benefits }\end{array}$ & $\begin{array}{l}\text { Tourism } \\
\text { streetbook }\end{array}$ & $\begin{array}{l}\text { Concern on } \\
\text { local } \\
\text { tourism }\end{array}$ & $\begin{array}{l}\text { Local } \\
\text { conservation } \\
\text { item, } \\
\text { sustainability }\end{array}$ \\
\hline $\begin{array}{l}\text { this } \\
\text { dissertation } \\
{[2]}\end{array}$ & $\begin{array}{l}\text { To build streetscape that } \\
\text { can be used by all user } \\
\text { regardless sexes, ability and } \\
\text { ages based on principle of } \\
\text { universal design }\end{array}$ & $\begin{array}{l}\text { Universal } \\
\text { design } \\
\text { based } \\
\text { urban } \\
\text { streetbook }\end{array}$ & $\begin{array}{l}\text { Concern on } \\
\text { urban } \\
\text { streetscape }\end{array}$ & $\begin{array}{l}\text { Resumed, add } \\
\text { urban identity } \\
\text { concept, } \\
\text { universal } \\
\text { design based }\end{array}$ \\
\hline
\end{tabular}

\subsection{The Result}

This study developed and studied the answer for 3 urgent problems which stated above as research questions and originality. The urgent problems itself derivated from 7 previous streetscape research evaluation with principles of universal design and comparison between each research detailed characteristics.

Later on, the study of the sustainable streetscape design guideline will be constructed as:

1. urban design oriented specialized street design guidelines. This point indicated that every parameter and element were suited to urban design scope

2. universal design principles based study. The four and seven principles of universal design were integrated to all points of this study

3. addition of urban identity factors. Every part of the streetscapes shall has a theme and identity which sustained and linked to others part of the urban area. This identity may helps urban people memorized their cities.

The study already constructed 89 items of sustainable street developments on 8 design sections, such as : parking lots, bus stops/subway gates, linkage designs, street furnitures, street utilities, street materials, signages, and pedestrian spaces [2]. The design sections are universal (every streets have those design sections), however the quality and identity of each streets may be vary (depend on the surrounding environment). The more accessible, safety, adapatable, and supporting degree resulted higher quality and better sustainable environment, since it will be used continuesly by many people. 


\section{Conclussion}

This study has constructed and developed new guidelines from 7 streetscape guideline books which based on universal design principles. The study case of parking lot, bus stop/subway gate, linkage design, street furniture, street utilities, street materials and pedestrian areas can be applied directly to streetscapes in many countries. The scale is the level of guidelines application, started from the the partial until the most sustainable streetscape design related to the universal design which may resulted the more user friendly regardless their sexes, abilities, ages, etc.

\section{References}

1. V. Meht, Lively Streets: Exploring The Relationship Between Built Environment And Social Behavior (2006)

2. B. Indrakusumo, Design Characteristics of Specialized Streets for Indonesia through Cases of South Korea (2016)

3. F. Aslaksen, S. Bergh, O.R. Bringa, E.K. Heggem; Universal design: Planning and Design for All (1997)

4. E. Burton, M. Lynee, Inclusive Urban Design: Street for Life (2006)

5. Department of Transport, Manual for Street (2007)

6. B.A. Putra, Cultural Representation of Vernacular Housing in Jambi (2013)

7. Islington Council, Islington Streetbook A borough-wide streetscape manual (2005)

8. Guide Dogs on Behalf of Action for Blind People, Inclusive Streets:Design Principles for Blind and Partially Sighted People (2010)

9. Abu Dhabi Urban Planning Council, Abu Dhabi Utility Corridor Design Manual ver 1 (2017)

10. Landcome, Street Project guideline (2008)

11. Otak Team, Scottsdale Road Streetscape Design Guidelines (2008)

12. Torbay council ,Torbay Streetscape Design Guidelines (2004)

13. V. Shehu, Universal Design Strategies On Developing Country, Case Study: Tirana (2011)

14. M. Guimares, An Assessment Of Understanding Universal Design Through Online Visual Resources and Role-Playing Simulation Exercises (2005) 